\title{
A Short Analysis of Rule-based Linguistic Knowledge
}

\author{
Meisam Rahimi \\ English Language Department, Faculty of Foreign Languages, University of Isfahan, Isfahan, Iran \\ Manijeh Youhanaee \\ English Language Department, Faculty of Foreign Languages, University of Isfahan, Isfahan, Iran \\ Hossein Barati \\ English Language Department, Faculty of Foreign Languages, University of Isfahan, Isfahan, Iran
}

\begin{abstract}
It is widely accepted by both linguists and psycholinguists that our implicit linguistic knowledge consists of both abstract rules that enable speakers to construct sentences productively and exemplars that are represented in the form of unanalyzable chunks that are memorized, stored and accessed as wholes. There are two major perspectives towards the rules of language: generativist and emergentist. In this study rule-based linguistic knowledge is looked at concisely from these two perspectives and some studies concerning some related issues are introduced briefly. At the end, a possible new perspective towards our rule-based linguistic knowledge, suggested by O'Grady (2008), is introduced.
\end{abstract}

Index Terms - linguistic knowledge, rule, generativism, emergentism

\section{INTRODUCTION}

It is commonly recognized both by linguists (e.g. Nattinger \& DeCarrico, 1992) and second language acquisition researchers (Myles, Mitchell \& Hooper, 1999) that a substantial part of our linguistic knowledge is composed of formulaic chunks. Cognitive psychologists also believe in the existence of both formulaic chunks and abstract rules (Hulstijn, 2002).

The interest observed in the early years of the twenty-first century in how L2 rules (morphology and syntax) are acquired has not decreased in the previous two decades (Macaro, 2010). The interlanguage concept was suggested independently in the late 1960s early 1970s (Adjémian, 1976). It was pointed out that interlanguage is systematic and rule-governed. This led to the suggestion that the acquired language by L2 learners, like native speakers, is represented in the form of a complex linguistic system.

Since SLA research advocate diverse theoretical positions, different Therefore, theory-driven hypothesis are guiding the research issues in this field (Juffs, 2011). Therefore, a problem-solving approach towards SLA research is emphasized by influential scholars (Long, 2007; VanPatten \& Williams, 2007). Certain issues have been closely associated with the acquisition of the L2 grammar:

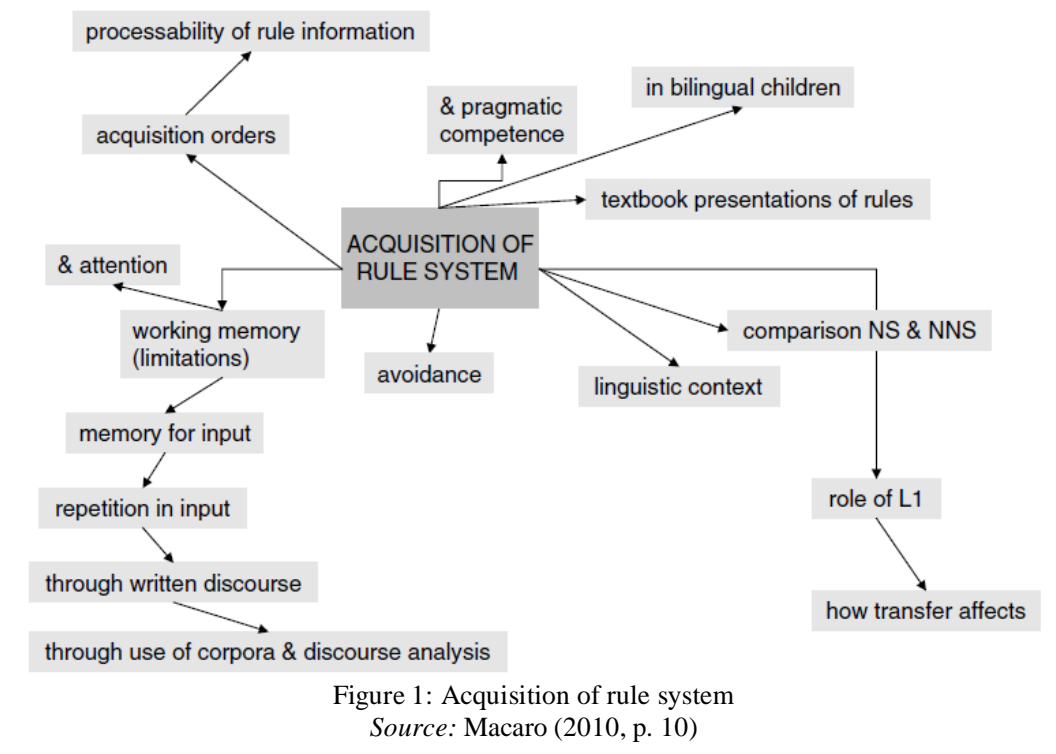


These areas of interest, in many respects, deal with constraints being placed on the acquisition of the L2 rule-system. They are sometimes looked at from a general perspective. For example, considering the studies of Pienemann (2005), Goldschneider and DeKeyser (2001), Hulstijn and De Graaff (1994) and N. Ellis (1996), R. Ellis (2009) considers the following factors as the criteria which can be used to determine the difficulty of grammatical features as implicit knowledge:

(1) Frequency (i.e. the frequency with which grammatical features appear in the input) (N. Ellis, 1996, 2002). However, the order in which implicit knowledge of different grammatical features is acquired cannot be accounted for just through frequency (see, e.g. Gass \& Mackey, 2002).

(2) Saliency (i.e. whether the grammatical feature can be easily noticed in the input) (Goldschneider \& DeKeyser, 2001)

(3) Functional value (i.e. whether there can be an association between a clear, distinct meaning and a grammatical feature) (Andersen, 1984)

(4) Regularity (whether a grammatical feature and some identifiable pattern can be associated) (Hulstijn \& De Graaff, 1994)

(5) Processability (whether the grammatical feature can be easily processed) (Pienemann, 2005)

According to this theory, the sequence of acquisition and learning difficulty is determined by the nature of the processing procedure employed in producing a specific grammatical feature.

However, generally speaking, the research questions which deal with these areas or the acquisition of a rule system are underpinned by two major theories of acquisition (Macaro, 2010; for alternative approaches to second language acquisition refer to Atkinson, 2011). The first theory deals with the relationship between language and the human brain: since languages have things which are the same in all languages (universal properties), it might be the case that human brain, at birth, already is 'set up' to learn all languages in a certain way (a theory of linguistic competence). The second theory sets a comparison between the human brain, or rather human memory, and an extremely powerful and intelligent computer which processes received information and acquires the rules through developing patterns of language as it is used by others (an emergentist theory). In spite of the great body of research conducted in this respect, many attempts are still made to validate one of these theories against the other regarding morpho-syntax.

\section{EMERGENTISM}

The arguments in favor of some kind of biological basis for the acquisition of the first language are renowned (e.g. Chomsky, 1986; Gregg, 2003; O’Grady, 1997; Pinker, 1994). However, it might be argued that an innate capacity for language acquisition is not domain specific but rather general and that cognitive principles involved in learning other things than language might be involved (O'Grady, 1997, 2003, 2008). Certainly, there is substantial evidence that other primates use a large portion of the perceptual system used by humans for speech (e.g., Hauser, Newport \& Aslin, 2001; Fitch, Hauser \& Chomsky, 2005). The same point is observable regarding the conceptual system. First, there might no be a correspondence between semantic representations and linguistic objects (Jackendoff, 2002). Second, there is a possibility that a foundation which is shared with other animals is the basis of the conceptual structure communicated by language (Fitch et al., 2005; Pinker \& Jackendoff, 2005).

The concept of modularity, proposed by UG, in the sense that language is set apart from other higher cognition in the form of a distinct module of the mind is denied by many cognitive linguists (Tomasello, 2003, 2005). However, in order to be able to be able to explain the acquisition of different aspects of phonology and morpho-syntax elaborate sets of categories that might emerge from input and that may be abstract are required. Cognitive linguists put emphasis on probability and frequency patterns in language structure instead of a priori rules and constructs.

Emergentism focus on frequency, the cognitive constraints on processing as sources of regularity and universals, communicative function of language, and reduces the significance of abstract constraints on structure (N. Ellis, 2007; MacWhinney, 2008; Tomasello, 2005). This perspective is completely different from the Chomskyan approach. Instead of abstract features, idea is that the structure of language is driven from communicative events and needs. The prototype theory of psychology where prototypes emerge from 'chunks' or different instances of a form is the key to learning and representation (Taylor, 2008). The Prototypes can include syntactic structures, the lexicon, and phonology. Besides, conscious learning can play a role in emergentists, unlike some generative researchers (N. Ellis, 2007). The work of Shirai and coworkers is considered as one of the most significant statements in the use of prototype theory in SLA (Andersen \& Shirai, 1996; Li \& Shirai, 2000). This work explained the development of aspect and tense marking in English and other languages.

Emergentist perspectives learning process is based on the input matching with communicative notions and situations such as saliency and frequency in the input. The term 'cue' is used by many emergentists in, for example, morphology for case marking, word order, gender and plurals, but they do not consider them as part of a closed system which is separate from all other higher cognition. In a series of studies, MacWhinney and his collaborators conducted a series of carefully limited experiments in order to provide some evidence to show that basic syntactic acquisition and representation depend on the strength of cues such as animacy, case marking and word order (Kempe \& MacWhinney, 1998; MacWhinney, 2008). The idea is that the cues used for showing grammatical relations are different among languages. MacWhinney argued that combinations of different cues vary across different languages and that the L1 
patterns compete with, or influence, the L2 patterns. This competition explains developmental patterns and errors, leading to the name of the framework, the 'Competition Model'.

Hawkins (2008) points out to a curious fact about contraction and agreement in English: a many speakers use plural NPs in the contracted form there's, but refuse to use it in its uncontracted counterpart:

(1) a. There's two books on the table.

b. *There is two books on the table.

Source: Hawkins (2008)

In total, it seems that here's and there's (and to a lesser extent where's) demonstrate an 'antiagreement effect': they demonstrate the default third person singular form irrespective of the number and person properties of the associated NP. One possibility, proposed by O'Grady (2008), is that the observed phenomenon is the effects of both contraction and grammaticalization, a process that is highly sensitive to frequency and often accompanies contraction (e.g., Bybee, 2003; Tomasello, 2003).

The emergentist perspective as well as formal linguistic approach consider L1 to have great effect on the developing L2 from. However, apart from the effect of the L1, the two approaches are different from each other significantly.

\section{UNIVERSAL GRAMMAR}

UG is considered to be part of an innate language faculty which is biologically endowed and enables the L1 acquirer to develop a grammar based on exposure to input (e.g. Chomsky, 1981b; Pinker, 1994; Crain, Goro \& Thornton, 2006). Accordingly, UG determines how grammars can be based on a genetic blueprint. In other words, UG provides a repertoire of possible grammatical features and categories in the widest sense (i.e. syntactic, semantic, morphological and phonological), placing requirements on the form of grammars. Furthermore, it determines the computational system can be in its nature, that is, the kinds of operation which can occur and principles that grammars follow and in this way it constrains the functioning of grammars.

This perspective assumes that language consists of modules (is modular) in two ways. First, it is believed that purely formal linguistic principles are to be separated from other forms of higher cognition and should be considered as significantly independent of the communicative role language. Second, those principles within the language module are separate from each other; for example, formal structures for phonology and syntax may be independent of each other (Jackendoff, 2002). It is also believed that this linguistic module incorporates invariable principles, that is, principles generally shared across different languages and parameters which lead to variation from language to language. Parametric differences between grammars are sometimes considered to be the result of properties of lexical items, especially so-called functional categories (Chomsky, 1995; Ouhalla, 1991; White, 2003a). Changes have occurred in formalization of universal principles and parameters as linguistic theories (e.g. Government-Binding, Minimalism, Optimality Theory) have developed. Parameters have been largely associated with the lexicon, hence being more constrained. Nonetheless, irrespective of how UG is formalized, it is generally accepted (within the generative linguistic perspective) that some particular properties of language are so subtle, complex and abstract their acquisition is not possible without the assumption that there are some innate linguistic constraints on grammar acquisition and grammars (White, 2003b).

A fundamental claim of parameter theory, introduced in the Principles and Parameters framework, is that a cluster of apparently dissimilar syntactic properties can be brought about by a single parameter setting (Chomsky, 1981a). This idea of clustering is supported by some evidence from L1 acquisition research, demonstrating that properties associated with a parameter setting emerge almost simultaneously (e.g. Snyder \& Stromswold, 1997).

The model of acquisition based on UG states that the child's initial state (S0) is comprised of UG constitutes. As the child is exposed to primary linguistic data (PLD), a language-specific lexicon is created and parameters values of UG are set according to the language, forming the precise form of the grammar. The grammar (G) may be altered over time as the child becomes sensitive to various input features. Eventually, a steady state grammar for the mother tongue (SS) would be obtained. Figure 2 represents this model of acquisition:

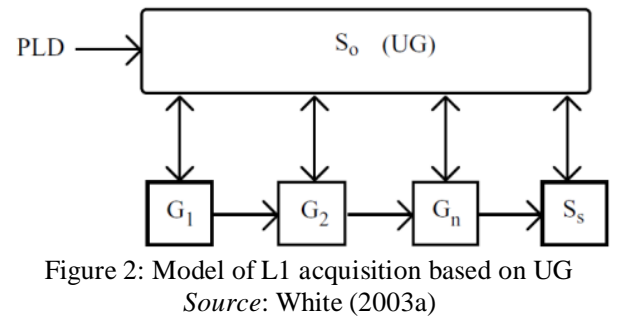

Like L1 acquisition, it has been argued that L2 learners are faced with a similar task in acquiring a system accounting for L2 input. Furthermore, L2 learners are also to cope, at least potentially, with the problem that there is an incongruity between abstract, complex and subtle properties of grammar and the L2 input (a logical problem of language acquisition) (Schwartz \& Sprouse, 2000). For such reasons, L2 researchers try to identify situations where the existing grammatical 
knowledge together with available L2 input cannot explain acquisition unless one accepts that UG constrains interlanguage grammars (Schwartz \& Sprouse, 2000; White, 1990).

As hypotheses about UG access developed, interest began to shift from central questions such as 'Is UG available?' to a closer investigation of the nature of the interlanguage grammar, particularly whether interlanguage grammars demonstrate properties typical of natural language (e.g. Martohardjono \& Gair, 1993; Thomas, 1991a; White, 1992). The issues of the mediation of UG in L2 acquisition and the extent of this access has been studied and discussed since the early 1980s. The first decade of research on UG in L2 acquisition focused mainly on the so called access issue, that is, whether there is any access to UG in non-primary acquisition (Cook, 1997; Schwartz, 1990; White, 1996).

Formerly, lack of total success in acquiring a grammar like that of a native speaker was interpreted as the absence of UG (e.g. Bley-Vroman, 1990; Schachter, 1990). Later, it was argued that UG can constrain an interlanguage grammar which diverges from the native grammar (MacLaughlin, 1996; Lightfoot, 1999; White, 1996, 2003a)

The focus of generative SLA studies for over two decades has been on finding answers to such questions as whether there is an equivalence between grammar a second language and a knowledge system parallel to the system which operates in an first language, whether it is initiated like an L1 but develops differently over time and whether it is a system not constrained by UG at all (Juffs, 2011). The table 1 represents the various positions taken towards these questions. These positions are briefly discussed in the following sections.

\section{A. UG-impaired Interlanguage Grammars}

The first major perspective is referred to as the no access position (Cook \& Newson, 1996; Epstein, Flynn \& Martohardjono, 1996). This position is expressed through by the Fundamental Difference Hypothesis (Bley-Vroman, 1990) and some related ideas (Clahsen \& Felser, 2006). This position argues that interlanguage grammars are not (fully) constrained by UG and that they suffer from local or global impairment.

The Global Impairment Hypothesis claims that there is a radical breakdown in interlanguage representations (parametric system) at any point in development (Clahsen \& Hong, 1995; Neeleman \& Weerman, 1997). The initial state is not explicitly discussed in this position. It seems that the possibility of L1 parameter settings is being rejected altogether (White, 2003a). Considering this perspective, end-state grammars are completely different from the grammars of native speakers and in fact totally different from natural language grammars (not constrained by UG). It has been tried to be argued that L2 input is in fact sufficient to induce the relevant contrasts without resort to principles of UG (Kellerman \& Yoshioka, 1999).

TABLE 1:

L2 ACQUISITION AND UG: INITIAL TO STEADY STATE

\begin{tabular}{|c|c|c|c|c|c|}
\hline & \multicolumn{2}{|l|}{ UG-impaired } & \multicolumn{3}{|l|}{ UG-constrained } \\
\hline & Global Impairment & Local Impairment & $\begin{array}{l}\text { No Parameter } \\
\text { Resetting }\end{array}$ & $\begin{array}{l}\text { Full Access } \\
\text { (without Transfer) }\end{array}$ & $\begin{array}{l}\text { Full Transfer Full } \\
\text { Access }\end{array}$ \\
\hline Initial state & $?$ & $\begin{array}{l}\text { L1 grammar + inert } \\
\text { features }\end{array}$ & L1 grammar & UG & L1 grammar \\
\hline Development & $\begin{array}{l}\text { Pattern matching; separate } \\
\text { constructions }\end{array}$ & $\begin{array}{l}\text { Some L2 properties } \\
\text { acquirable. Features } \\
\text { remain inert. }\end{array}$ & $\begin{array}{l}\text { No parameter } \\
\text { resetting }\end{array}$ & $\begin{array}{l}\text { Parameter setting, } \\
\text { directly to L2 } \\
\text { values }\end{array}$ & $\begin{array}{l}\text { Parameter } \\
\text { resetting (L1 to } \\
\mathrm{L} n)\end{array}$ \\
\hline $\begin{array}{l}\text { Final } \\
\text { outcome }\end{array}$ & $\begin{array}{l}\text { Grammar } \\
\text { essentially different from } \\
\text { native-speaker grammar. } \\
\text { L2-like grammar not } \\
\text { attainable. }\end{array}$ & $\begin{array}{l}\text { Features still inert. } \\
\text { L2-like grammar not } \\
\text { attainable. }\end{array}$ & $\begin{array}{l}\text { L1-like grammar. } \\
\text { L2-like grammar } \\
\text { not attainable. }\end{array}$ & L2-like grammar. & $\begin{array}{l}\text { L2-like grammar } \\
\text { possible but not } \\
\text { inevitable. }\end{array}$ \\
\hline
\end{tabular}

Source: White (2003a)

The Local Impairment Hypothesis provides another proposal for defective grammars. According to this hypothesis there is a local breakdown in interlanguage grammars. This breakdown is claimed to be related to inert feature values. This claim implies that interlanguage grammars are not fully UG-constrained. According to the Local Impairment Hypothesis, not only in the initial state but also the developmental states and even in the steady state are expected to be characterized by the inertness (Lardiere, 1998a, b).

\section{B. UG-constrained Interlanguage Grammars}

In contrast to approaches that interlanguage grammars defective are the various claims that maintain that interlanguage grammars are UG-constrained in all stages of development from the initial to the steady state (Cook \& Newson, 1996; Juffs, 2004; White \& Juffs, 1998). The differentiating factor in these Hypotheses is the extent to which the L1 grammar is involved in interlanguage representations. On the one hand, No Parameter Resetting Hypothesis claims that interlanguage grammars have access only to those parameter settings which were realized in the first language, implicating that subsequent parameter resetting is impossible (Bley-Vroman, 1990; Clahsen \& Muysken, 1989; Schachter, 1990; Sorace, 1993). However, the results of the study conducted by Montrul and Slabakova (2003) suggested that the steady-state grammar of L2 Spanish speakers characterizes aspectual contrasts not realized in the L1, hence demonstrating that L2 speakers cannot be restricted to L1 features. 
Finally, there are two perspectives which claim full access to UG. In other words, not only UG constrains interlanguage grammars but also L2 learners and L2 speakers can go beyond the L1 grammar representations. According to these hypotheses, the parameters of UG can be set or reset to L2 values. Full Access (without Transfer) hypothesis, the first hypothesis, claims that L1 grammar plays no role in interlanguage representations, initially or subsequently (Flynn, 1996). The Full Transfer Full Access Hypothesis proposes that both UG and the L1 grammar influence the functioning and form of the interlanguage grammar (Cook \& Newson, 1996; Hale, 1996; Schwartz \& Sprouse, 1996; White, 2003a). According to this hypothesis, the initial state of the interlanguage is completely based on the L1 grammar and that restructuring occurs in response to L2 input and within the bounds of UG (Inagaki, 2001; Thomas, 1991b, 1993).

\section{CONCLUSION}

According to O'Grady (2008), the aim of emergentism is not to repudiate the UG-based perspective but to develop a more suitable version of the innateness hypothesis. He believes that many different possibilities are included in this enterprise and perhaps considering one single position as appropriate at this time is premature. However, he considers that certain promising lines of inquiry might be discerned such as the idea that many of the classic mysteries that at first inspired curiosity in Universal Grammar can be illuminated through a processor which is sensitive to frequency as well as computational efficiency.

\section{REFERENCES}

[1] Adjémian, C. (1976). On the nature of interlanguage systems. Language Learning, 26, 297-320.

[2] Andersen, R. (1984). The one to one principle of interlanguage construction. Language Learning, 34, 77-95.

[3] Andersen, R. \& Shirai, Y. (1996). The primacy of aspect in first and second language acquisition: the pidgin-creole connection. In W. Ritchie, \& T. Bhatia (Eds.) Handbook of Second Language Acquisition (527-570). New York, NY: Academic Press.

[4] Atkinson, D. (2011). Alternative approaches to second language acquisition. London, UK: Routledge.

[5] Bley-Vroman, R. (1990). The logical problem of foreign language learning. Linguistic Analysis, 20, 3-49.

[6] Bybee, J., (2003). Mechanisms of change in grammaticization: the role of frequency. In B. Joseph \& R. Janda, (Eds.), The Handbook of Historical Linguistics (pp. 602-623). Blackwell, Oxford.

[7] Chomsky, N. (1981a). Lectures on government and binding. Dordrecht: Foris.

[8] Chomsky, N. (1981b). Principles and parameters in syntactic theory. In N. Hornstein \& D. Lightfoot (Eds.), Explanation in linguistics: the logical problem of language acquisition (pp. 32-75). London, UK: Longman.

[9] Chomsky, N. (1986). Knowledge of language: its nature, origin, and use. New York, NY: Praeger.

[10] Chomsky, N. (1995). The minimalist program. Cambridge, MA: MIT Press.

[11] Clahsen, H. \& Felser, C. (2006). Grammatical processing in language learners. Appl Psycholinguist, 27, 3-42.

[12] Clahsen, H. \& Hong, U. (1995). Agreement and null subjects in German L2 development: new evidence from reaction-time experiments. Second Language Research, 11, 57-87.

[13] Clahsen, H. \& Muysken, P. (1989). The UG paradox in L2 acquisition. Second Language Research, 5, 1-29.

[14] Cook, V. (1997). Monolingual bias in second language acquisition research. Revista Canaria de Estudios Ingleses, 34, 35-49.

[15] Cook, V. \& Newson, M. (1996). Chomsky's Universal Grammar: an introduction. Oxford: Blackwell.

[16] Crain, S., Goro, T. \& Thornton, R. (2006). Language acquisition is language change. Journal of Psycholinguistic Research, 35, 31-49.

[17] Ellis, N. (1996). Sequencing in SLA: Phonological memory, chunking, and points of order. Studies in Second Language Acquisition, 18, 91-126.

[18] Ellis, N. (2002). Frequency effects in language processing. Studies in Second Language Acquisition, 24, 143-188.

[19] Ellis, N. (2007). The associative-cognitive creed. In B. VanPatten, J. Williams (Eds.), Theories in Second Language Acquisition: An Introduction (77-96). Mahwah, NJ: Lawrence Erlbaum Associates.

[20] Ellis, R. (2009). Investigating Learning Difficulty in Terms of Implicit and Explicit Knowledge. In R. Ellis, S. Loewen, C. Elder, R. Erlam, J. Philp \& H. Reinders, Implicit and Explicit Knowledge in Second Language Learning, Testing and Teaching. Bristol, UK: Multilingual Matters.

[21] Epstein, S., Flynn, S. \& Martohardjono, G. (1996). Second language acquisition: theoretical and experimental issues in contemporary research. Brain and Behavioral Sciences, 19, 677-758.

[22] Fitch, W.T., Hauser, M. \& Chomsky, N. (2005). The evolution of the language faculty: clarifications and implications. Cognition, 97, 179-210.

[23] Flynn, S. (1996). A parameter-setting approach to second language acquisition. In W. Ritchie \& T. Bhatia (Eds.), Handbook of language acquisition (pp. 121-58). San Diego: Academic Press.

[24] Gass, S. \& Mackey, A. (2002) Frequency effects and second language acquisition: A complex picture? Studies in Second Language Acquisition, 24, 249-260.

[25] Goldschneider, J. M., \& DeKeyser, R. M. (2001). Explaining the "natural order of L2 morpheme acquisition" in English: A meta-analysis of multiple determinants. Language Learning, 51, 1-50.

[26] Gregg, K. (2003). The state of emergentism in second language acquisition. Second Language Research, 19, 95-128.

[27] Hale, K. (1996). Can UG and the L1 be distinguished in L2 acquisition? Brain and Behavioral Sciences, 19, 728-30.

[28] Hauser, M., Newport, E., Aslin, R. (2001). Segmentation of the speech stream in a nonhuman primate: statistical learning in cotton-top tamarins. Cognition, 78, 53-64.

[29] Hawkins, R. (2008). Current emergentist and nativist perspectives on second language acquisition. Lingua, 118(4), 445-446. 
[30] Hulstijn, J. (2002). Towards a unified account of the representation, processing and acquisition of second language knowledge. Second Language Research, 18 (3), 193-223.

[31] Hulstijn, J. H., \& De Graaff, R. (1994). Under what conditions does explicit knowledge of a second language facilitate the acquisition of implicit knowledge?: a research proposal. Aila Review, 11, 97-112.

[32] Inagaki, S. (2001). Motion verbs with goal PPs in the L2 acquisition of English and Japanese. Studies in Second Language Acquisition, 23, 153-70.

[33] Jackendoff, R. (2002). Foundations of Language. New York, NY: Oxford University Press.

[34] Juffs, A. (2004). Representation, processing and working memory in a second language. Trans Phil Soc, 102, $199-226$.

[35] Juffs, Alan (2011). Second language acquisition. WIREs Cognitive Science, 2, 277-286 DOI: 10.1002/wcs.106.

[36] Kellerman, E. \& Yoshioka, K. (1999). Inter- and intra-population consistency: a comment on Kanno (1998). Second Language Research, 15, 101-9.

[37] Kempe, V., MacWhinney, B. (1998). The acquisition of casemarking by adult learners of Russian and German. Stud Second Lang Acquis, 20, 543-588.

[38] Lardiere, D. (1998a). Case and tense in the 'fossilized' steady state. Second Language Research, 14, 1-26.

[39] Lardiere, D. (1998b). Dissociating syntax from morphology in a divergent end-state grammar. Second Language Research, 14, $359-75$.

[40] Lightfoot, D. (1999). The development of language: acquisition, change and evolution. Oxford: Blackwell.

[41] Long, M. H. (2007). Problems in SLA. New York, NY: Lawrence Erlbaum.

[42] Macaro, E. (2010). Second Language Acquisition: The Landscape, the Scholarship and the Reader. In E. Macaro (Ed.), Continuum Companion to Second Language Acquisition. London, UK: Continuum.

[43] MacLaughlin, D. (1996). Second language acquisition of English reflexives: is there hope beyond transfer. In A. Stringfellow, D. Cahana-Amitay, E. Hughes \& A. Zukowski (eds.), Proceedings of the 20th Annual Boston University Conference on Language Development (pp. 453-64). Somerville, MA: Cascadilla Press.

[44] MacWhinney, B. (2008). A unified model. In P. Robinson, N. Ellis (Eds.), Handbook of cognitive linguistics and second language acquisition (pp. 341-371). New York, NY: Routledge.

[45] Martohardjono, G. \& J. Gair. (1993). Apparent UG inaccessibility in second language acquisition: misapplied principles or principled misapplications? In F. Eckman (Ed.), Confluence: linguistics, L2 acquisition and speech pathology (pp. 79-103). Amsterdam, The Netherland: John Benjamins.

[46] Montrul, S. \& Slabakova, R. (2003). Competence similarities between native and nearnative speakers: an investigation of the preterite/imperfect contrast in Spanish. Studies in Second Language Acquisition, 25(3), 351-398.

[47] Myles, F., Mitchell, R. \& Hooper, J. (1999). Interrogative Chunks in French L2: a basis for creative construction . Studies in Second Language Acquisition, 21(1), 49-80.

[48] Nattinger, J. R. \& DeCarrico, J., S. (1992). Lexical phrases and language teaching. Oxford, UK: Oxford University Press.

[49] Neeleman, A. \& Weerman, F. (1997). L1 and L2 word order acquisition. Language Acquisition, 6, 125-70.

[50] O'Grady, W. (1997). Syntactic development. Chicago: University of Chicago Press.

[51] O'Grady, W. (2003). The radical middle: nativism without Universal Grammar. In C. Doughty \& M. Long (Eds.), Handbook of second language acquisition. Oxford: Blackwell.

[52] O'Grady, W. (2008). Innateness, universal grammar, and emergentism. Lingua, 118 (4), 620-631.

[53] Ouhalla, J. (1991). Functional categories and parametric variation. London: Routledge.

[54] Pienemann, M. (2005) An introduction to processability theory. In M. Pienemann (Ed.), Cross-linguistic Aspects of Processability Theory (pp. 1-60). Amsterdam, The Netherland: John Benjamins.

[55] Pinker, S. (1994). The language instinct. New York, NY: William Morrow and Co.

[56] Pinker, S., Jackendoff, R., (2005). The faculty of language: what's special about it? Cognition, 97, 201-236.

[57] Schachter, J. (1990). On the issue of completeness in second language acquisition. Second Language Research, 6, 93-124.

[58] Schwartz, B. D. (1990). Un-motivating the motivation for the fundamental difference hypothesis. In H. Burmeister \& P. Rounds (Eds.), Proceedings of the 10th Second Language Research Forum (pp. 667-84). American English Institute, University of Oregon.

[59] Schwartz, B. D. \& Sprouse, R. (1996). L2 cognitive states and the full transfer/full access model. Second Language Research, $12,40-72$.

[60] Schwartz, B. D. \& Sprouse, R. (2000). The use and abuse of linguistic theory in L2 acquisition research. In A. Juffs, T. Talpas, G. Mizera \& B. Burtt (Eds.), Proceedings of GASLA IV (pp. 176-87). University of Pittsburgh Working Papers in Linguistics.

[61] Selinker, L. (1972). Interlanguage. International Review of Applied Linguistics 10: 209-31.

[62] Snyder, W. \& Stromswold, K. (1997). The structure and acquisition of English dative constructions. Linguistic Inquiry, 28, 281-317.

[63] Sorace, A. (1993). Incomplete and divergent representations of unaccusativity in nonnative grammars of Italian. Second Language Research, 9, 22-48.

[64] Taylor, J. R. (2008). Prototypes in cognitive linguistics. In P. Robinson, N. Ellis (Eds.), Handbook of Cognitive Linguistics and Second Language Acquisition (39-65). London, UK: Routledge.

[65] Thomas, M. (1991a). Do second language learners have 'rogue' grammars of anaphora. In L. Eubank (Ed.), Point counterpoint: Universal Grammar in the second language (pp. 375-88). Amsterdam, The Netherland: John Benjamins.

[66] Thomas, M. (1991b). Universal Grammar and the interpretation of reflexives in a second language. Language, 67, 211-39.

[67] Thomas, M. (1993). Knowledge of reflexives in a second language. Amsterdam, The Netherland: John Benjamins.

[68] Tomasello, M. (2003). Constructing a language. A usage-based theory of language acquisition. Cambridge, MA: Harvard University Press.

[69] Tomasello, M. (2005). Beyond formalities. The Linguistic Review, 22(2-4), 183-197.

[70] VanPatten, B. \& Williams, J. (2007). Theories in Second Language Acquisition: An Introduction. London, UK: Routledge. 
[71] White, L. (1992). Subjacency violations and empty categories in L2 acquisition. In H. Goodluck \& M. Rochemont (Eds.), Island Constraints (pp. 445-64). Dordrecht: Kluwer.

[72] White, L. (1996). Universal grammar and second language acquisition: current trends and new directions. In W. Ritchie \& T. Bhatia (Eds.), Handbook of language acquisition (pp. 85-120). New York, NY: Academic Press.

[73] White, L. (2003a). Fossilization in steady state L2 grammars: Persistent problems with inflectional morphology. Bilingualism: Language and Cognition, 6, 129-141.

[74] White, L. (2003b). Second Language Acquisition and Universal Grammar. UK: Cambridge University Press.

[75] White, L., Juffs, A. (1998). Constraints on Wh-movement in two different contexts of non-native language acquisition: competence and processing. In S. Flynn, G. Martohardjono \& W. O'Neill (Eds.), TheGenerative Study of Second Language Acquisition (111-130). Hillsdale, NJ: Erlbaum.

Meisam Rahimi is a PhD student in Teaching English as a Foreign Language (TEFL) at the University of Isfahan. His areas of interest include computational linguistics, computer-assisted language learning (CALL) and language acquisition.

Manijeh Youhanaee holds a PhD in language and linguistics from the University of Essex. She has co-authored with Badrizadeh "A Descriptive Dictionary of Theories of Generative Grammar". She has published a number of articles on the teaching/ acquisition of different English syntactic properties by native speakers of Persian. She teaches MA and PhD courses in linguistics, generative grammar, TEFL and SLA. Her areas of interest include syntactic theory, acquisition of L2 \& L3 syntax and issues in teaching and learning English as a second/foreign language.

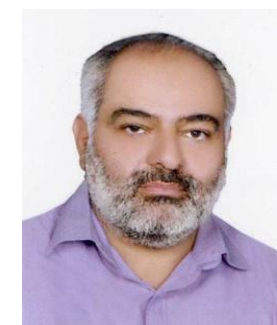

Hossein Barati works in the English department, University of Isfahan, where he is assistant Professor of Applied Linguistics. He has a PhD in "Language Testing" from University of Bristol and has been involved in research in language testing, programme evaluation, reading strategies, and classroom discourse. Before becoming a university lecturer in 1992, he worked as a language teacher at Ministry of Education, Isfahan, Iran. He has published in areas of language testing and assessment, and language programme evaluation. He is a member of a research project on Developing a new model of teaching to adult English non-majors at University of Isfahan, funded by University of Isfahan. He has also co-authored some publications on DIF in Iranian National University Entrance Exam (INUEE), 2007; Linguistic constraints and language teaching, 2008; and Cultural differences in EFL performance on cloze tests, 2010. Further a text-book A step forward in English for intermediate EFL learners is among his latest publications. Dr. Barati is currently working on 'New plans for Teaching English to Iranian adult non-majors', Teaching English to Iranian young learners, and, The consequential validity of high stakes tests in the Iranian context'. 